\title{
Eutrophication, toxic cyanobacteria and cyanotoxins: when ecosystems cry for help
}

\author{
Vitor Vasconcelos
}

CIMAR - Marine and Environmental Research Center - Rua dos Bragas, 177, 4050-PORTO - and Department of Zoology and Anthropology - Faculty of Sciences - Porto University, Praça Gomes Teixeira, 4050-009 Porto, Portugal. Email - vmvascon@fc.up.pt

\begin{abstract}
Eutrophication of freshwater resources has been studied worldwide and its consequences are of concern especially in waters used for recreation or drinking. The occurrence of cyanobacteria blooms is nowadays much better documented and among the major impacts we may point out the decrease in water transparency and oxygen levels, the production of off-flavours and the production of toxins. Among the most common toxins, microcystins, anatoxin-a and saxitoxins are the most common in Portugal. A diversity of microcystins has been identified so far but microcystin-LR is the most common. Many aquatic organisms are capable to resist certain levels of cyanotoxins making them vectors for toxins. We analysed this possibility using a diversity of cyanotoxins and organisms and found that microcystins and bivalves seem to be the combination that maximizes toxin transfer. New challenges are presented today in this research area, by using new and more sensitive chemical, biochemical and molecular techniques. This allows us to better understand these organisms that can produce both potent toxins and innovative drugs.
\end{abstract}

Keywords: eutrophication, toxic cyanobateria, cyanotoxins, toxin transfer.

\section{RESUMEN}

La eutrofización de las aguas dulces ha sido estudiada por todo el mundo y sus consecuencias son una preocupación en aguas utilizadas para ocio o para beber. La ocurrencia de florecimientos de cianobacterias esta hoy mucho mejor documentada y entre los impactos más grandes podemos destacar la disminución de la transparencia del agua y de los niveles de oxigeno disuelto, la producción de olores y sabores y de toxinas. De entre las toxinas más comunes, las microcistinas, anatoxina-a y saxitoxinas son las más comunes en Portugal. Hasta ahora identificamos una gran diversidad de microcistinas pero la microcistina-LR es la más común. Muchos organismos acuáticos pueden resistir a ciertos niveles de cianotoxinas, haciendo que sean vectores de toxinas. Analizamos esta posibilidad utilizando una diversidad de cyanotoxinas y de organismos y encontramos que las microcistinas y los bivalvos parecen ser la combinación que maximiza la transferencia de toxinas. Hoy se nos presentan nuevos desafios en esta área de investigación, utilizando técnicas químicas, bioquímicas y moleculares nuevas y más sensibles. Esto nos permite entender mejor estos organismos que pueden producir potentes toxinas y nueva drogas.

Palabras clave: eutrofización, cianobacterias tóxicas, cianotoxinas, transferencia de toxinas.

\section{EUTROPHICATION AND PHYTOPLANKTON BLOOMS}

The natural evolution of aquatic ecosystems may lead to their eutrophication even when anthropogenic influence is scarce or absent. This is clearly seen in natural lakes and rivers in remote areas such as the Amazon region (Tundisi, 1990) or high altitude lakes in Switzerland (Mez et al.,
1996). The runoff of nutrients and organic matter is due to accumulate especially in lakes and ponds or slow flowing rivers. This problem is accelerated whenever man influences the water quality of a river basin. In fact, we may consider that eutrophication has been accelerated and anthropogenic influence on water quality has its starting point, since early civilizations started to use manure to increase crops productivity, such 
as those of the ancient Egypt. Intensive agriculture, cattle domestication, and the industrial revolution later are important dates to consider whenever eutrophication is to be analysed.

Most of the studies on eutrophication seem to be focused on freshwater ecosystems but this does not mean that only these systems are affected. In fact, considering the relationship between surface area and water volume, freshwater systems are much more influenced by any external or internal source of contamination than open ocean areas.

The increase in nutrients, especially phosphorus and nitrogen in their diverse forms, is usually pointed out as the main cause of eutrophication. The sources may vary but we should separate natural and anthropogenic ones. Natural sources may be leaf decay in the rivers, lixiviation of nutrients from sites upstream a given waterbody, and natural forest fires that later contribute to increase in $\mathrm{N}$ and $\mathrm{P}$ loads. Nevertheless, what we want to stress here are the anthropogenic causes. Domestic and industrial effluents, agriculture activities (pesticides and fertilizers), and inadequate management of watersheds, all may be pointed out as the major causes of eutrophication. The building of dams in rivers may also be pointed out as an activity that may accelerate eutrophication processes.

The consequences of eutrophication are usually associated with low water quality. Either the heavy development of aquatic macrophytes, some of them real nuisances, or the production of large phytoplankton blooms, are both clear signs of this phenomenon in more recent times. Macrophytes such as water lilies (Nymphaea spp.), the water hyacinth, (Eichornia crassipes) or the aquatic fern Azolla, are some of the organisms responsible for heavy changes in water quality, leading to drastic situations in many systems. We may give as examples the disastrous occurrence of Azolla in Guadiana river (Baioa \& Carrapiço, 1998) or more recently the occurrence of water hyacinth in the northern Portuguese Cávado River. These developments usually imply the use of heavy machinery to remove the biomass produced.
Nevertheless, the occurrence of phytoplankton blooms in eutrophic rivers is the most common effect of eutrophication and, in spite of their minute size compared to macrophytes, bloom forming phytoplankton organisms can cause severe damages to ecosystems and human health. Although there is a diversity of phytoplankton groups that can produce water blooms, those that can cause the most severe negative effects in terms of freshwater quality are dinoflagelates, diatoms, and cyanobacteria.

Dinoflagelates are well studied in marine and estuarine ecosystems because they can develop blooms -red tides- with significant impact from both an economical and a human health perspectives. They are responsible for human intoxications via vectors such as bivalve molluscs, producing in some cases lethal effects (Yasumoto, 1990). Nevertheless, there are no records of toxic dinoflagelate species in freshwater ecosystems. The negative effects can be, apart from some water discoloration, lethal effects on fish populations due to gill clot or gill perforation. This can lead to significant impacts on the economy as well as on the ecology of aquatic freshwater resources. On the other side, bloom-forming diatoms in freshwater systems may produce changes in water quality by the production of organic volatile substances that change the organoleptic characteristics of the water. This is especially important for sources of drinking water. These compounds are not known to be toxic to humans but whenever they contaminate water used for drinking, it results in the need of switch to a different water source. Many times these other sources are not controlled in adequate ways and may cause damages to human health.

The most common phytoplankton organisms associated with eutrophication of freshwater systems are cyanobacteria. In fact, these organisms can form blooms leading to very high cell densities causing severe changes in water quality with not yet well estimated economic losses.

Some of the main effects due to cyanobacteria blooms comprise a decrease in water transparency, heavy fluctuation of oxygen levels and release of toxins. As stated, cyanobacteria 
blooms are responsible for the decrease in water transparency, and this can pose ecological and safety problems. During a heavy bloom, water transparency can be as low as 1$2 \mathrm{~cm}$ so this disturbs the whole ecology of the ecosystem by preventing light from reaching higher water depths. Only species able to migrate in the water column such as cyanobacteria can be successful in this type of environment. On the other side, animals that use sight to move, locate food, or find partners to mate will also be severely affected during these cyanobacteria blooms. The huge cyanobacteria biomass that composes these blooms may produce high amounts of oxygen during daytime leading to over saturation. The high respiration of all aquatic organisms during nighttime may lead then to a drop in oxygen concentration during night. Especially in areas close to the bottom or the thermocline, the oxygen levels at night may be low enough to produce the death of the more sensitive species such as some fish. The variation in $\mathrm{pH}$, with high values over nine during daytime and low levels at night may also stress the environment and cause changes in the biogeochemistry that can increase the negative effects stressed before. Last but not least, many cyanobacteria species and strains are able to produce bioactive compounds with toxic properties. These toxins can cause death not only to aquatic organisms that come in direct contact with them but also to livestock, domestic animals, waterfowl and in some cases to humans.

\section{TOXIC AND NONTOXIC CYANOBACTERIA}

Cyanobacteria are well-studied organisms because they are old, they can form blooms, they produce substances that may be used as pharmaceuticals, and because they are toxic. The stromatolites found in Australia show that these organisms are almost as old as life on earth and that we owe them the presence of an oxygenic atmosphere. On the other side, cyanobacteria can be found in different envi- ronments such as Artic and Antarctic lakes (Skulberg, 1996), hotsprings (Castenholz, 1973) or Waste Water Treatments Plants (Vasconcelos \& Pereira, 2001).

Although many papers dealing with cyanobacteria focus on their negative impact on ecosystems, an increasing number of studies show that cyanobacteria are able to synthesize compounds with interesting biological activity. In many cases these substances may be used as pharmaceutical drugs.

A study by Francis (1878) in Australia, described poisoning of cattle after they had drunk water from a cyanobacteria contaminated lake. Following that study, scientists started to focus their attention on toxic cyanobacteria. The evolution of the discovery of new toxins is still ongoing. Today, more than 84 variants of cyanotoxins are described although only minor a fraction of them are well studied (Sivonen and Jones, 1999). The effects of the cyanotoxins in animals were not the only ones reported. Although according laboratory experiments one might believe that these toxins could harm humans, only recently these expectations were sadly confirmed by a human fatality occurred in Caruaru, Brazil (Jochimsen et al., 1998). More than 60 people died following the hemodyalisis sessions done with not well-treated water from an eutrophic reservoir (Jochimsen et al., 1998).

In spite of the diversity of toxins found so far, some cyanobacteria species and some strains within reported toxic species are not able to produce these toxins. The knowledge of the molecular mechanisms associated with the synthesis of these toxins was supposed to teach us about their function. During recent years a major effort by several leading laboratories around the world has been done to try to solve this problem. Genes used for the synthesis of microcystins, the most studied group of cyanotoxins have been isolated and characterized from several different cyanobacteria species (Fujiki et al., 2002, Rouhiainen et al., 2004), but until now we do not know why some species/strains have these toxins and what are the advantages or disadvantages of having them. 
Table 1. Main cyanotoxins and genera responsible for their production in Portuguese freshwaters. Principales cianotoxinas y géneros responsables de su producción en aguas continentales portuguesas.

\begin{tabular}{lll}
\hline TOXIN & GENERA & REFERENCE \\
\hline Microcystins & & \\
$\begin{array}{l}\text { MC-LA, MC-LR, MC-AR, MC-YR, MC-RR, [D-Asp } 3 \text { ]MC-LR } \\
{\left[\mathrm{Dha}^{7}\right] \text { MC-LR, [L-MeSer7]MC-LR }}\end{array}$ & Microcystis & $\begin{array}{l}\text { Vasconcelos } \text { et al., } 1995 \\
\text { Vasconcelos } \text { et al., } 1996\end{array}$ \\
$\begin{array}{l}\text { MC-HilR } \\
{[\mathrm{D}] \text { MC-LR, MC-FR, MC(H4)-YR, MC-WR }}\end{array}$ & & Saker et al., 2005a \\
\hline Anatoxin-a & Anabaena & Osswald et al. (not Published) \\
\hline Saxitoxins & & \\
$\begin{array}{l}\text { GTX5, GTX6, neoSTX, dcSTX, STX } \\
\text { GTX1, GTX3, GTX4 }\end{array}$ & Aphanizomenon & Pereira et al., 2000 \\
\hline Unknown toxins & & Ferreira et al., 2000 \\
Cylin. Type toxin & Cylindrospermopsis & Saker et al., 2003a, 2003b \\
\hline
\end{tabular}

\section{CYANOTOXIN DIVERSITY IN PORTUGAL}

Cyanobacteria and cyanotoxins can be found in many different types of aquatic systems both natural and man-made. Due to their preference for ecosystems not very much disturbed from a physical point of view they tend to bloom in slow flowing rivers such as Minho, Douro, Tejo, or Guadiana (Vasconcelos, 2002, Vasconcelos et al., 1993, 1996). Also natural lakes such of those of the central Portugal region between Aveiro and Figueira da Foz - Mira and Quiaios lakes - have heavy toxic cyanobacteria blooms during some months of the year (Vasconcelos et al., 1996). Other systems such reservoirs that are used as drinking water sources like Torrão, Bravura and Aguieira have recorded toxic cyanobacteria blooms (Vasconcelos et al., 1996, Saker et al., 2005). Other man-made systems such as Waste Water Treatment Plants - WWTP- may hold cyanobacteria populations with toxin production (Oudra et al., 2000, Vasconcelos \& Pereira, 2001). Toxins found in these systems may not only be responsible for changes in the microbial dynamics of the WWTP leading to lower efficiencies on organic matter metabolization, but they can also contaminate sites located downstream (Vasconcelos \& Pereira, 2001).
Most of the reported toxic occurrences in Portugal are due to the cyanotoxins microcystins. A diversity of microcystins has been described so far with more than 13 variants analysed (Table 1).

Microcystin-LR (MC-LR) is the most common microcystin found both in natural blooms (Vasconcelos et al., 1996) or strains isolated and characterized in laboratory (Vasconcelos et al., 1995, Saker et al., 2005). Nevertheless, other less common variants were identified from both strains and blooms such as MC-Hilr or MC-WR.

The neurotoxins of the paralysing shellfish toxin group -saxitoxins, gonyautoxins, and C-toxins were reported from two reservoirs, one in the northern Douro river- Crestuma reservoir (Ferreira et al., 2000) and another in the southern Montargil reservoir (Pereira et al., 2000, Dias et al., 2002) (Table 1). The risks associated with the consumption of water contaminated with these toxins are low, compared to the microcystins. However, due to the absence of sublethal effects, they may accumulate in aquatic organisms and transferred through food chains. This is a serious problem in marine systems being the causes of many human deaths all over the world.

The other neurotoxin, anatoxin-a, was only recently described from our freshwaters (data 
not published). Several strains of Anabaena sp. and Oscillatoria sp. were shown to produce this neurotoxin but not much is known about its regional distribution in Portugal.

Cylindrospermopsis raciborskii is an invasive cyanobacteria that was first assigned to tropical and subtropical environments such as Australia and Brazil (Lagos et al., 1999; Saker \& Griffiths, 2001), but in the last decade its distribution has spread to the northern hemisphere. Many countries in Europe have now reported its occurrence although the toxin cylindrospermopsin is not always associated (Couté et al., 1997). In Portugal we have reported the occurrence of this species in several central and south lakes and reservoirs (Saker et al., 2003a,b). Toxicological analysis of strains isolated from these sites showed lethal toxicity using mouse bioassays (Saker et al., 2003a). Nevertheless, chemical analysis did not identify the presence of cylindrospermopsin (Table $1)$. Other toxin or toxins with similar action may be involved.

The changes that our climate is prone to, namely global warming, may increase the occurrence of more invasive cyanobacteria species in temperate climates. Bird migration and the importation of items from tropical countries may also bring resistant cells from cyanobacteria -akinets- that may germinate where adequate environment conditions are found.

\section{TOXIN TRANSFER: IS THERE A RISK?}

Cyanobacteria toxins may have lethal effects on many aquatic or terrestrial organisms but others are less sensitive to intoxication. The need for the toxin to enter blood circulation, associated to the fact that many organisms might have different and more effective detoxification systems and lack transporters of the cyanotoxins to their blood system, may led to the possibility of toxin transfer through food chains. One important aspect is the fact that most of the cyanotoxins are not lipophilic, so they should not have a high tendency to accumulate along food chains. Nevertheless, the simple fact that a crustacean or a mollusc may feed on toxic cyanobacteria turn them potential vectors at least when they have their gut content full of toxic organisms. In fact it was shown that half of the toxin content of molluscs contaminated with microcystins is due to the gut load of this toxin (Vasconcelos, 1995, Amorim \& Vasconcelos, 1999). In table 2, a summary of maximum cyanotoxin values found in a diversity of aquatic organisms is shown.

Our research has shown that although microcystins are mostly hydrophilic, some organisms can accumulate them. Molluscs are those that can reach the higher levels, mostly due to their feeding behaviour being candidates for trophic toxin transfer. Nevertheless, most organisms may detoxify microcystins via GST metabolic pathway, and this

Table 2. Maximum cyanotoxin levels found in molluscs, crustaceans and fish, both in natural and laboratory situations (dw- dry weight, wwwet weight). Niveles máximos de cianotoxina hallados en moluscos, crustáceos y peces, tanto en condiciones naturales como en el laboratorio (dw-peso seco, ww-peso húmedo).

\begin{tabular}{lcll}
\hline Toxin & $\begin{array}{c}\text { Maximum concentration } \\
(\boldsymbol{\mu g} / \mathbf{g})\end{array}$ & \multicolumn{1}{c}{ Organism } & \multicolumn{1}{c}{ Reference } \\
\hline MC-LR & $10.50 \mathrm{dw}$ & Mytilus galloprovincialis & Vasconcelos, 1995 \\
& $10.70 \mathrm{dw}$ & M. galloprovincialis & Amorim \& Vasconcelos, 1999 \\
$2.90 \mathrm{dw}$ & Procambarus clarkii & Vasconcelos et al., 2001 \\
& $0.25 \mathrm{dw}$ & Cyprinus sp. & Vasconcelos, 2001 \\
& $11.0 \mathrm{dw}$ & Dreissena polymorpha & Pires et al., 2004 \\
CYL & $2.52 \mathrm{dw}$ & Anodonta cygnea & Saker et al., 2004 \\
& $4.30 \mathrm{dw}$ & Cherax quadricarinatus & Saker \& Eaglesham, 1999 \\
PST & $0.26 \mathrm{ww}$ & Anodonta cygnea & Pereira et al., 2004 \\
\hline
\end{tabular}


counteracts the bioaccumulation tendency (Pflugmacher et al., 1998, Wiegand et al., 1999). Other animals such as fish or crayfish cannot accumulate such high levels. Cylindrospermopsin and saxitoxins do not attain such high levels even when molluscs accumulate them. So, in terms of human health, the major problems associated with cyanotoxin accumulation by freshwater organisms may be posed by microcystins.

\section{NEW CHALLENGES ON TOXIC CYANOBACTERIA RESEARCH}

Until recently, cyanobacteria identification had been done using the traditional taxonomic methods for phytoplankton analysis, by using morphological characteristics as the main basis. Nevertheless, these methods have been proven not satisfactory in many occasions such as when studying isolates that may change their size, shape and colony characteristics when in culture. So the need for new techniques that could be used for both naturally collected species and laboratory isolates led to the development of molecular techniques for the identification of cyanobacteria species (Neilan et al., 1997 Saker et al., 2005b). On the other hand, the discovery of the gene sequences responsible for the production of the most common cyanotoxins (Fujiki et al., 2002, Rouhiainen et al., 2004) was a breakthrough in this area. Nowadays, a single colony may be enough to provide many answers with regard to the presence of gene clusters responsible for a possible toxin production. By using immunoassays such as ELISA (Ueno et al., 1996) we may quantify the total load of toxin present in a given time by a colony or flake of filaments of cyanobacteria. The development of more sophisticated techniques in the chemical, biochemical or molecular biology fields is needed, in order to provide us with tools to better understand the function of cyanotoxins in ecosystems.

The search for new biologically active compounds produced by cyanobacteria is also challenging. Recently, we found that marine strains of cyanobacteria are able to inhibit thrombininduced blood platelet activation, with decreased
P-selectin expression, platelet aggregation, and shedding of platelet-derived micro-vesicules (Selheim et al., 2005). Platelet anti-aggregatory treatment is a major task for the prevention of cardiovascular diseases. On the other side, some of the strains tested showed preferential apoptogenic activity against SH-SY5Y-neuroblastoma cells without causing apoptosis in a kidney epithelian cell line, fibroblasts and two lines (rat and human) of leukaemia cells (Selheim et al., 2005). The results we got so far indicate that cyanobacteria, apart from producing potent toxins may also be important sources of cell biology compounds and drug development.

The knowledge that we have up until now concerning eutrophication of freshwaters, allow us to predict that in many situations it will not be easy to slow this process down. The visible signs that eutrophic ecosystems send us are a clear "cry for help" as it is our responsibility to retard and reverse this process. Monitoring programmes concerning toxic cyanobacteria in recreational and drinking water bodies are needed, but other natural systems are important as well because toxins may affect all trophic levels. Decrease of nutrient loads should be considered as the major measure to effectively retard eutrophication.

\section{ACKNOWLEDGMENTS}

First of all I want to dedicate this work to Prof. Ramon Margalef, who I met not only through his Ecología and Limnología books but also during a Limnology course in Zaragoza in 1988. His kindness and simplicity was a great envelope for his comprehensive knowledge of Ecology and the mysteries still in need to be solved to better understand the functioning of our world. I also want to thank the Editors of this publication for the invitation to present this paper.

\section{REFERENCES}

AMORIM, A. \& V. VASCONCELOS. 1999. Dynamics of microcystins in the mussel Mytilus galloprovincialis. Toxicon, 37: 1041-1052 
BAIOA, M. V. \& F. CARRAPIÇO. 1998 - The Azolla bloom in the Mértola region: a sociological approach. Proceedings of the 10th EWRS International Symposium on Aquatic Weeds - Management and Ecology of Aquatic Plants. pp. 233-235.

CASTENHOLZ, R. A., 1973. Ecology of blue-green algae in hotsprings. In: The Biology of Blue-green algae. N. G. Carr and B. A. Whitton, (eds): 379414. Blackwell Scientific Publications., Oxford.

COUTÉ, A., M. LEITÃO \& C. MARTIN. 1997. Premiére observation du genre Cylindrospermopsis (Cyanophyceae, Nostocales) en France. Cryptogamie Algol.,18: 57-70.

DIAS, E., P. PEREIRA, S. FRANCA. 2002. Production of paralytic shellfish toxins by Aphanizomenon sp. LMECAY31 (Cyanobacteria). $J$. Phycol., 38: 705-712.

FERREIRA, F., J. SOLER, L. FIDALGO, P. FERNADEZ. 2000. PSP toxins from Aphanizomenon flos-aquae (cyanobacteria) collected in the Crestuma reservoir (Douro river, Northern Portugal). Toxicon, 39: 757-761.

FRANCIS, G., 1878. Poisonous Australian Lake. Nature, 18: 11-12.

FUJII, K., K. SIVONEN, T. NAKANO \& K. I. HARADA. 2002. Structural elucidation of cyanobacterial peptides encoded by peptide synthetase gene in Anabaena species. Tetrahedron, 58: 68636871.

JOCHIMSEN, E. M., W. W. CARMICHAEL., J. D. M ANCARDO, S. T. COOKSON; C. E. M. HOLMES, M. B. ANTUNES, T. M. LYRA, V. S. T. BARRETO, S. M. F. O AZEVEDO, W. R. JARVIS. 1998. Liver failure and death after exposure to microcystins at a hemodyalisis center in Brazil. New Engl J. Med., 338:873-878.

LAGOS, N., H. ONODERA, P. A. ZAGATTO, S. M. ANDRINOLO, S. M. F. AZEVEDO \& Y. OSHIMA. 1999. The first evidence of paralytic shellfish toxins in the freshwater cyanobacterium Cylindrospermopsis raciborskii, isolated from Brazil. Toxicon, 37: 1359-1373.

MEZ, K., K. HANSELMAN, H. NAEGELI \& H. R. PERISIG, 1996. Protein phosphatase-inhibiting activity in cyanobacteria from alpine lakes in Switzerland. Phycologia, 35: 133-139.

NEILAN, B. A., D. JACOBS, T. DEL DOT, L. L. BLACKALL, P. R. HAWKINS, P. T. COX \& A. E. GOODMAN. 1997. rRNA sequences and evolutionary relationships among toxic and non-toxic cyanobacteria of the genus Microcystis. Int. J. Syst. Bacteriol., 47: 69-97.
OUDRA B., D. M. EL ANDALOUSSI, S. FRANCA, P. BARROS, R. MARTINS, K. OUFDOU, B. SBIYYAA, M. LOUDIKI, N. MEZRIOUI \& V. VASCONCELOS. 2000. Harmful cyanobacterial toxic blooms in waste stabilisation ponds. Wat. Sci. \& Technol. 42: 179-186.

PEREIRA, P., H. ONODERA, D. ANDRINOLO, S. FRANCA, F. ARAÚJO, N. LAGOS \& Y. OSHIMA. 2000. Paralytic shellfish poisoning toxins in the freshwater cyanobacterium Aphanizomenon flos-aquae, isolated from Montargil reservoir, Portugal. Toxicon, 38: 1689-1702.

PFLUGMACHER, S., C. WIEGAND, A. OBEREMM, K. A. BEATTIE, E. KRAUSE, G. A. CODD \& C. E. W. STEINBERG. 1998. Identification of an enzymatically-formed glutathione conjugate of the cyanobacterial hepatotoxin microcystin-LR. The first step of detoxication. Biophysica et Biochimica Acta, 1425: 527-533.

ROUHIAINEN, L., T. VAKKILAINEN, B. LUMBYE SIEMER, W. BUIKEMA, R. HASELKORN, \& K. SIVONEN. 2004. Genes coding for the synthesis of hepatotoxic heptapeptides (microcystins)in the cyanobacterium Anabaena strain 90. Appl. Environ. Microbiol. 70(2): 686-692.

SAKER, M. \& G. K. EAGLESHAM. 1999. The accumulation of cylindrospermopsin from the cyanobacterium Cylindrospermopsis raciborskii in tissues of the Redclaw crayfish Cherax quadricarinatus. Toxicon, 37:1065-1077.

SAKER, M. L. \& D. J. GRIFFITHS. 2001. Occurrence of blooms of the cyanobacterium Cylindrospermopsis raciborskii (Woloszynska) from a north Queensland domestic water supply. Mar. Freshwat. Res., 52: 907-915.

SAKER, M. L., J. FASTNER, E. DITTMANN, G. CHRISTIANSEN \& V. M. VASCONCELOS, 2005a. Variation between strains of the cyanobacterium Microcystis aeruginosa isolated from a Portuguese river. J. Applied Microbiology, 99:749757.

SAKER, M. L., A. D. JUNGBLUT, B. NEILAN, T. RAWN \& V. M. VASCONCELOS. 2005b. Detection of microcystin synthethase genes in health food supplements containing the freshwater cyanobacterium Aphanizomenon flos-aquae. Toxicon, 46: 555-562.

SAKER, M. L., I. R. NOGUEIRA, V. M. VASCONCELOS, B. A. NEILAN, G. K. EAGLESHAM \& P. PEREIRA. 2003a. First report and toxicological assessment of the cyanobacterium Cylindrospermopsis raciborskii from Portuguese 
freshwaters. Ecotoxicology and Environmental Safety, 55(2): 243-250.

SAKER, M. L., I. R. NOGUEIRA, V. M. VASCONCELOS. 2003b. Distribution and toxicity of Cylindrospermopsis raciborskii (Cyanobacteria) in Portuguese freshwaters. Limnetica, 22:131-138

SAKER, M. L., J. S. METCALF, G. A. CODD \& V. VASCONCELOS. 2004, Accumulation and depuration of the cyanobacterial toxin cylindrospermopsin in the freshwater mussel Anodonta cygnea. Toxicon, 43: 185-194.

SELHEIM, F., L. HERFINDAL. R. MARTINS. V. VASCONCELOS \& STEIN-OVE DOSKELAND. 2005. Neuro-apoptogenic and thrombocyte function modulating toxins in non-blooming marine cyanobacteria from the Portuguese coast. Aquatic Toxicology, 74:294-306.

SIVONEN, K. \& G. JONES. 1999. Cyanobacterial Toxins. In Toxic Cyanobacteria in Water. I. Chorus \& J. Bartram (eds): 41-111. E \& FN SPON \& WHO, Geneva.

SKULBERG, O. M. 1996. Terrestrial and limnic algae and cyanobacteria. In: A Catalogue of Svalvard Plants, Fungi, Algae and Cyanobacteria. Part 9, A. Elvebakk and P. Prestud (eds.) Norsk Polarinstitutt Skrifter 198: 383-395.

TUNDISI, J. G. 1990. Perspectives for ecological modeling of tropical and subtropical reservoirs in Soth America. Ecol. Modell, 52:7-20.

UENO,Y., S. NAGATA, T. TSUTSUMI, A. HASEGAWA, F. YOSHIDA, M. SUTAJJIT, D. MEBS \& V. VASCONCELOS. 1997. Survey of microcystins in environmental water by a highly sensitive immunoassay based on monoclonal antibody. Natural Toxins, 4: 271-276.

VASCONCELOS, V. 1995. Uptake and depuration of the peptide toxin microcystin-LR in the mussel Mytilus galloprovinciallis. Aquat. Toxicol., 32: 227-237.

VASCONCELOS, V. M. 2001. Cyanobacteria toxins: diversity and ecological effects. Limnetica, 20: 175-188.

VASCONCELOS, V. M. 2001. Toxic freshwater cyanobacteria and their toxins in Portugal. In:
Cyanotoxins - Occurrence, Effects, Controlling Factors. I. Chorus (ed.): 64-69. Springer Publishers, Heidelberg.

VASCONCELOS, V. 2002. Toxic cyanobacteria in the Mondego basin reservoirs. An overview. In Aquatic ecology of the Mondego river basin. Global importance of local experience. M. A. Pardal, J. C. Marques \& M. A. S. Graça (eds.) Chapter 2.2: 105-114, Imprensa da Universidade de Coimbra, Coimbra.

VASCONCELOS, V. W. EVANS, W. W. CARMICHAEL \& M. NAMIKOSHI. 1993. Isolation of microcystin-LR from a Microcystis (Cyanobacteria) bloom collected in the drinking water reservoir for Porto, Portugal. J. Env. Sci. Health., 28(9): 2081-2094.

VASCONCELOS, V., K. SIVONEN, W. R. EVANS, W. W.,CARMICHAEL \& M. NAMIKOSHI. 1995. Isolation and characterization of microcystins (heptapeptide hepatotoxins) from Portuguese strains of Microcystis aeruginosa Kutz. emed Elekin. Arch. Hydrobiol., 134: 295-305.

VASCONCELOS,V., K. SIVONEN, W. R. EVANS, W. W, CARMICHAEL \& M. NAMIKOSHI. 1996. Hepatotoxic microcystin diversity in cyanobacterial blooms collected in Portuguese freshwaters. Water Research, 30: 2377-2384.

VASCONCELOS, V. M., \& E. PEREIRA. 2001. Cyanobacteria diversity and toxicity in a Wastewater Treatment Plant (Portugal). Water Research, 35: 1354-1357.

VASCONCELOS V. M., S. OLIVEIRA \& L. F. OLIVA TELES. 2001. Effects of the toxic cyanobacterium Microcystis aeruginosa in the crayfish Procambarus clarkii . Toxicon, 39:1461-1470

WIEGAND, C., S. PFLUGMACHER, A. OBEREMM, N. MEEMS, K. BEATTIE, C. E. W. STEINBERG \& G. A. CODD. 1999. Uptake and Effects of Microcystin-LR on Detoxication Enzymes of Early Life Stages of the Zebrafish (Danio rerio). Environmental Toxicology, 14, 89-95.

YASUMOTO, T. 1990. Marine microorganisms toxins - an overview. In: Toxic Marine Phytoplankton, E. Graneli, B. Sundstrom, L. Edler \& D.M. Anderson (eds.): 3-8. Elsevier, New York. 